\title{
Energy simulation in buildings with the help of multi-criteria decision making method
}

\author{
Milena Medineckiene ${ }^{\mathrm{a}, \mathrm{b}}$, Rasa Dziugaite-Tumeniene ${ }^{\mathrm{b}}$ \\ ${ }^{a}$ Royal Institute of Technology, Brinellvagen 23, Stockholm 10044, Sweden \\ ${ }^{b}$ Vilnius Gediminas Technical University, Sauletekio al. 11, Vilnius 10223, Lithuania
}

\begin{abstract}
The article presents an investigation of the use of three methodologies in order to find the optimal combination of the technologies of the building energy system. The DesignBuilder software has been used to model the energy demand of the building. The Polysun software has been used to simulate the combinations of the technologies of the building energy system. The evolutionary solving method, integrated into MS Excel Solver, is applied for an optimization of the building energy system. The results of the optimization showed the necessity to use the decision making methods in order to select the rational combination of the energy system. Multi-criteria decision making methods WASPAS and TOPSIS are used in this case study. The main goal of this study is to find the rational combination of the technologies of the building energy system, considering the efficient energy use in the building, low impact to the environment and economic rationality. Five alternatives are foreseen to represent the energy use of the building. The results of the case study showed that the wood boiler with the integrated solar collector and photovoltaic systems are the rational configuration of the building energy system.
\end{abstract}

Keywords: multi-criteria; MCDM; WASPAS; TOPSIS; evolutionary solving method.

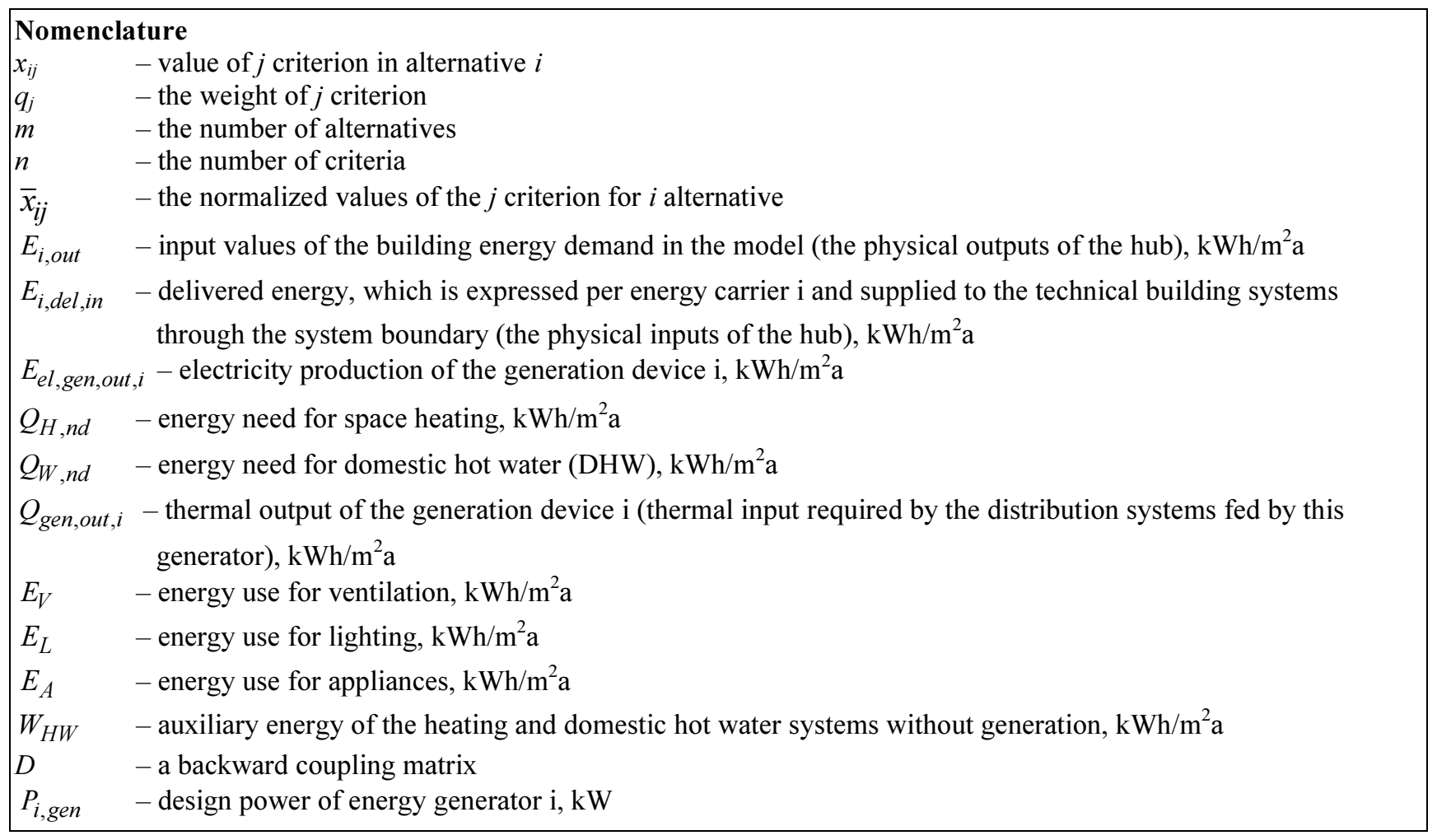

Corresponding author: Milena Medineckiene. E-mail address: milena.medineckiene@vgtu.lt

http://dx.doi.org/10.3846/enviro.2014.271

(C) 2014 The Authors. Published by VGTU Press. This is an open-access article distributed under the terms of the Creative Commons Attribution License, which permits unrestricted use, distribution, and reproduction in any medium, provided the original author and source are credited. 


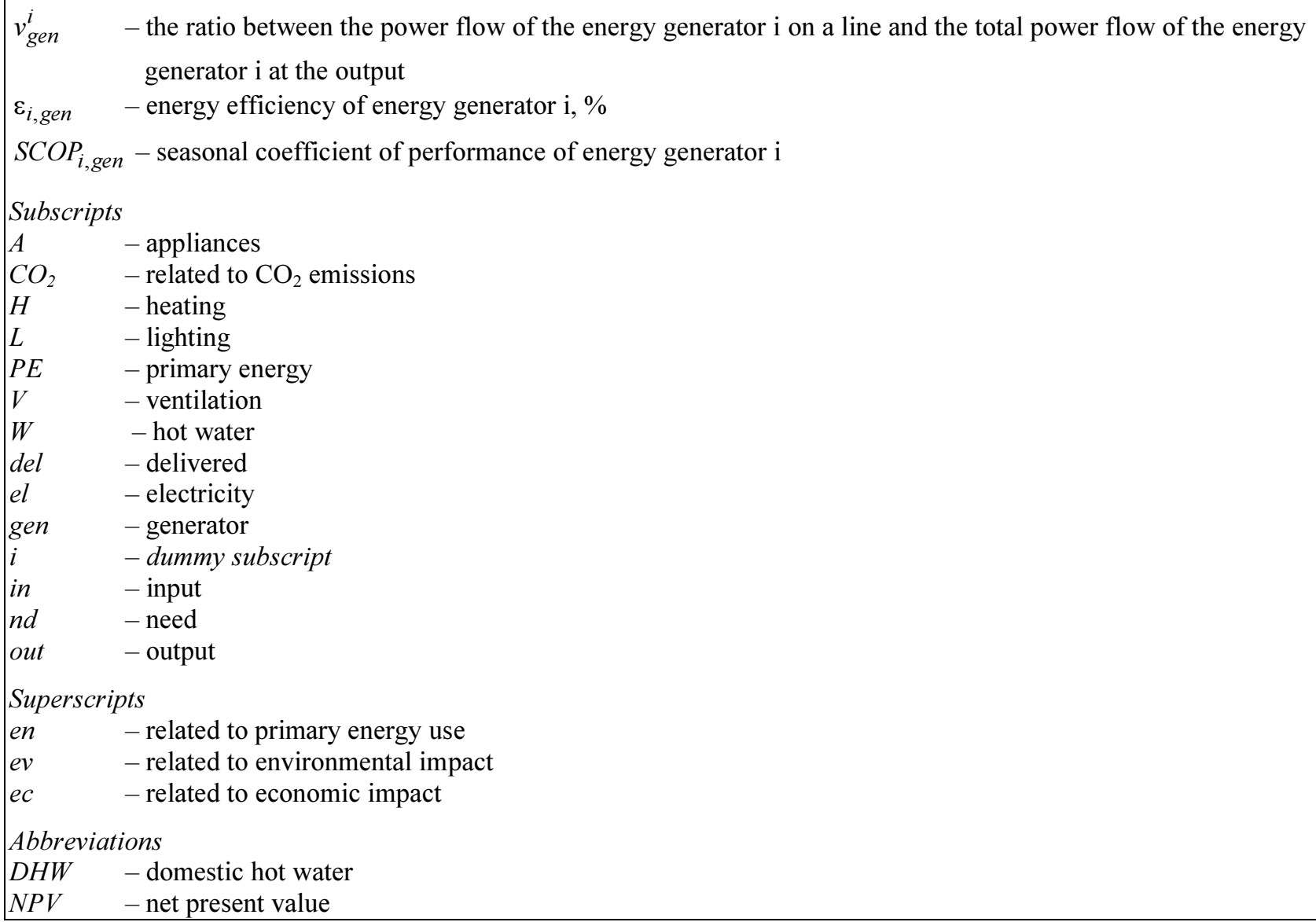

\section{Introduction}

During the past decade and particularly over the past five years, national policies in both Europe and the United States have begun to mandate requirements for new buildings and retrofits of existing buildings that are designed to achieve ambitious performance goals centered on renewable energy, climate change and improved energy performance [1]. Traditionally heating, cooling, lighting, ventilation, domestic electrical appliances are the main energy users of the building. Therefore, the main attention has been directed to reduce this energy use by implementing the technical innovations, regulatory control and assessing a wide range of rating methods [2]. The relevance of making building more environmental friendly nowadays is uncontended. Here the authors present the tool for choosing the rational option of the combination of the technologies of the building energy system. The article introduces the multi-criteria methodology, which is used for the calculations; describes the analyzed case study; adduces the results and presents the final conclusions.

\section{Methodology}

The evaluation and optimization algorithm of the building energy system, presented in Figure 1, is used in the case study [3]. The multi-criteria decision making methods WASPAS [4] and TOPSIS [5] are used for the final decision making in the rank of the configuration of the building energy system. WASPAS and TOPSIS are very useful methods in solving this kind of tasks, especially, if these methods are multidimensional [6]. Weights for each criterion are calculated with the help of AHP pair-wise comparison matrix [7], [8].

The WASPAS method's calculations are carried out with Eqns (1-4) and are described as follows:

- normalized values for WASPAS method:

$$
\begin{aligned}
& \bar{x}_{i j}=\frac{{ }_{i}^{o p t} x_{i j}}{x_{i j}} \text {, where } i=\overline{1, m} ; j=\overline{1, n} \\
& \text { if opt value is } \min
\end{aligned}
$$

- weighted and normalized values for the summarized part of WASPAS method:

$$
\bar{x}_{i j, \text { sum }}=\bar{x}_{i j} q_{j} \text {, where } i=\overline{1, m} ; j=\overline{1, n} \text {; }
$$




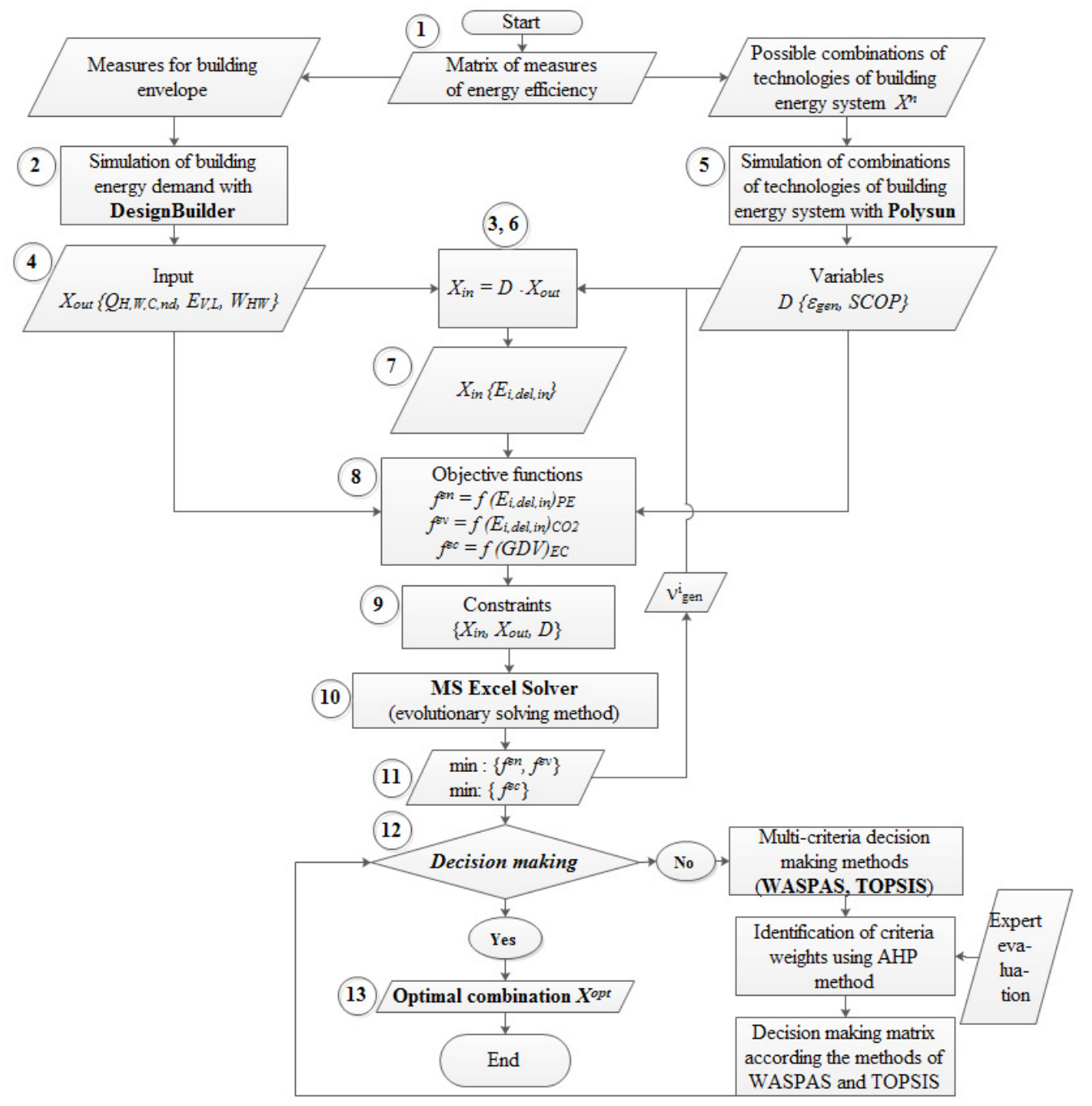

Fig. 1. Evaluation and optimization algorithm of building energy system

- weighted and normalized values for the multiplication part of WASPAS method:

$$
\bar{x}_{i j, m u l t}=\bar{x}_{i j} q_{j} \text {, where } i=\overline{1, m} ; j=\overline{1, n} \text {. }
$$

The final results of WASPAS calculation are carried out with this equation:

$$
W P S_{i}=0.5 \sum_{j=1}^{n} \bar{x}_{i j}+0.5 \prod_{j=1}^{n} \bar{x}_{i j}, \text { where } i=\overline{1, m} ; j=\overline{1, n} .
$$

The normalized values of TOPSIS method calculations are carried out with formula (5). Normalized and weighted values are carried out with the same equation (2) as for summarizing values for WASPAS method. The next steps of TOPSIS calculations are carried out with the Eqns (6-9) and (10).

$$
\bar{x}_{i j}=\frac{x_{i j}}{\sqrt{\sum_{i=1}^{m} x_{i j}^{2}}}, \text { where } i=\overline{1, m} ; j=\overline{1, n}
$$

Here and after $x_{\mathrm{ij}}$ is a value of $j$ criterion for $i$ alternative; $m$ - is a number of the alternative, $n$ - is the number of the criteria; $q$ - is the weight of the criterion.

$$
K_{i}=\frac{L_{i}^{-}}{L_{i}^{+}+L_{i}^{-}}
$$

where: $1 \geq K_{i} \geq 0, i=1,2,3, \ldots, m$. 


$$
\begin{aligned}
& L_{i}^{+}=\sqrt{\sum_{j=1}^{n}\left(\overline{\left.x_{i j}-\overline{x_{j}^{+}}\right)^{2}}\right.}, i=\overline{1, m} ; \\
& L_{i}^{-}=\sqrt{\sum_{j=1}^{n}\left(\overline{x_{i j}-\overline{x_{j}^{-}}}\right)^{2}}, i=\overline{1, m} \text {; }
\end{aligned}
$$

where $\overline{\overline{x_{j}^{+}}}$and $\overline{\overline{x_{j}^{-}}}$can be described as follows:

$$
\begin{aligned}
& D^{+}=\left\{\left(\max _{i} \bar{x}_{i j} \mid j \in J\right),\left(\min _{i} \bar{x}_{i j} \mid j \in J^{\prime}\right), i=\overline{1, m}\right\}=\left\{\overline{\overline{x_{1}^{+}}}, \overline{\overline{x_{2}^{+}}}, \ldots, \overline{\overline{x_{n}^{+}}}\right\} ; \\
& D^{-}=\left\{\left(\min _{i} \bar{x}_{i j} \mid j \in J\right),\left(\max _{i} \bar{x}_{i j} \mid j \in J^{\prime}\right), i=\overline{1, m}\right\}=\left\{\overline{\overline{x_{1}^{-}}, \overline{x_{2}^{-}}, \ldots, \overline{x_{n}^{-}}}\right\} ;
\end{aligned}
$$

\section{Case study}

The object of the case study is an existing low energy individual family house with five residents, located in Vilnius, Lithuania. The house is single storey, the useful floor area is $153.5 \mathrm{~m}^{2}$. The structural system of the building is a residual formworks system from polystyrene foam blocks. The physical basis of the system of polystyrene foam blocks is composed. The extra insulation of $15 \mathrm{~cm}$ polystyrene foam slabs is equipped on the exterior facades. The windows are with exceptionally low U values; triple-pane insulated glazing with air-seals and specially developed thermally-broken window frames. The ratio of windows and walls is $16 \%$. The thermal conductivity of the house components is presented in Table 1 .

Table 1. The thermal conductivity of house components

\begin{tabular}{ll}
\hline House component & $U, \mathrm{~W} / \mathrm{m}^{2} \mathrm{~K}$ \\
\hline External walls & 0.120 \\
Roof & 0.087 \\
Floor & 0.111 \\
Windows & 0.802 \\
External door & 1.20 \\
Linear thermal conductivity of thermal bridge: & $\Psi, \mathrm{W} / \mathrm{mK}$ \\
outside corner & -0.114 \\
roof & -0.095 \\
floor slab & -0.153 \\
window & 0.035 \\
\hline
\end{tabular}

The existing installed energy system of the house is an air-water heat pump. The normalized measured data, presented in Table 2, is used for the simulations of the combinations of the building energy systems.

Table 2. The thermal conductivity of house elements

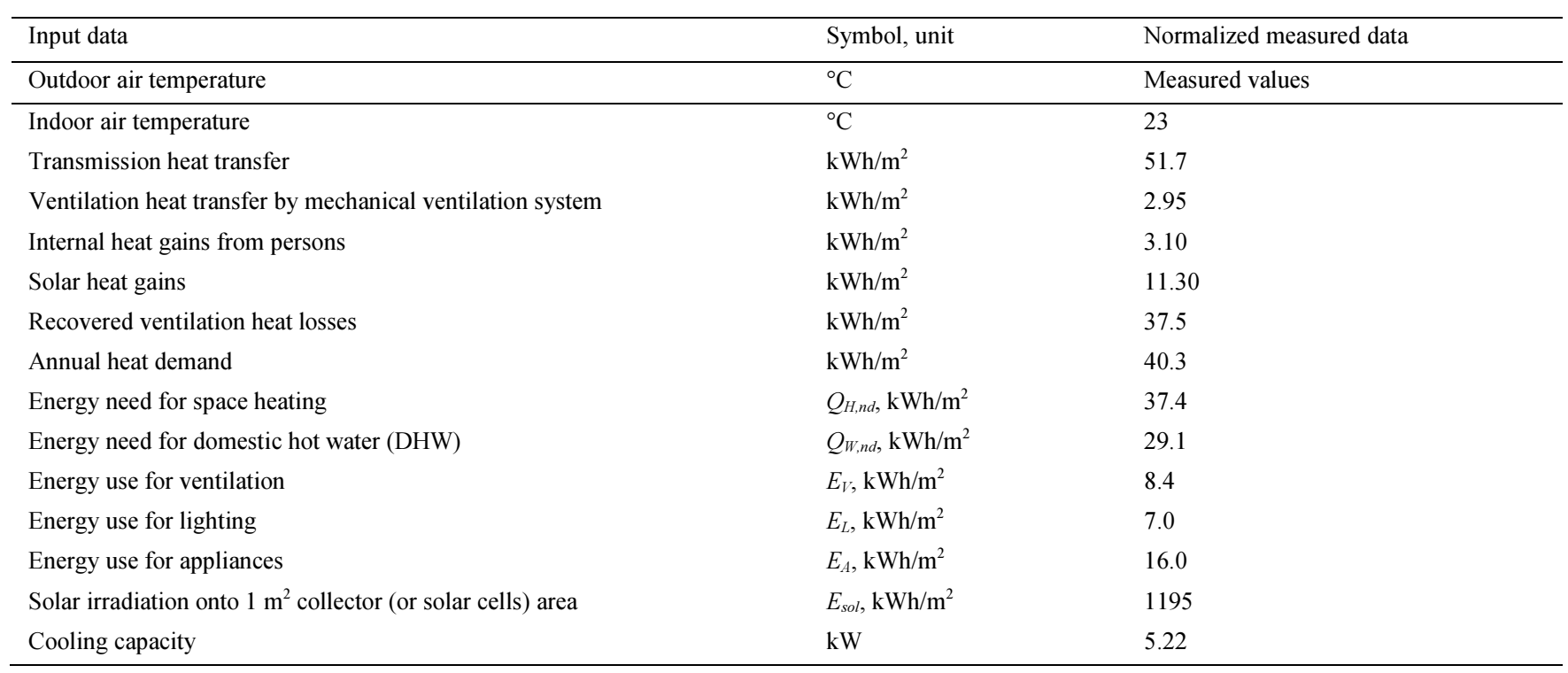


As can be seen from Table 2, the building energy demand for heating is in agreement to the requirements for the low energy house. In order to minimize the primary energy demand of non-renewable energy sources, environmental impact to the environment, the optimal combination of building energy system has to be selected. The combination of energy generators provides the possibility to meet the thermal and electrical loads. Thermal load can be met by: wood boiler, condensing boiler, air-to-water heat pump, ground-to-water heat pump, water-water heat pump, and solar collectors. The electricity can be met by: electricity from the grid, photovoltaic system. This case study presents five combinations of building energy systems: $D_{1}$ - wood boiler, solar collector system of $7.2 \mathrm{~m}^{2}$, photovoltaic system of $1.0 \mathrm{~m}^{2}$, electricity grid; $D_{2}$ - condensing gas boiler, solar collector system of $7.2 \mathrm{~m}^{2}$, photovoltaic system of $1.0 \mathrm{~m}^{2}$, electricity grid; $D_{3}-$ air-towater heat pump, solar collector system of $7.2 \mathrm{~m}^{2}$, photovoltaic system of $1.0 \mathrm{~m}^{2}$, electricity grid; $D_{4}-$ ground-to-water heat pump, solar collector system of $7.2 \mathrm{~m}^{2}$, photovoltaic system of $1.0 \mathrm{~m}^{2}$, electricity grid; $D_{5}$ - water-to-water heat pump, solar collector system of $7.2 \mathrm{~m}^{2}$, photovoltaic system of $1.0 \mathrm{~m}^{2}$, electricity grid. Decision making matrix with the minimized values of objective functions of the case is presented in Table 3.

Table 3. Decision making matrix with the minimized values of objective functions

\begin{tabular}{|c|c|c|c|c|c|}
\hline \multirow{2}{*}{ Energy generator } & \multicolumn{3}{|c|}{$\min f$} & \multicolumn{2}{|c|}{$\min \mathrm{f}$} \\
\hline & $v_{\text {gen }}^{\prime}$ & $\left(\mathbf{E}_{\mathrm{i}, \text { del,in }}\right)_{\mathrm{PE}}, \quad\left(\mathrm{kWh} \mathrm{h}_{\mathrm{PE}} /\right.$ year $)$ & $\left(\mathbf{E}_{\mathrm{i}, \text { del,in }}\right)_{\mathrm{CO} 2},\left(\mathrm{~kg}_{\mathrm{CO} 2} /\right.$ year $)$ & $v_{\text {gen }}^{\prime}$ & $\mathbf{G D V},(\mathrm{LTL})$ \\
\hline Wood boiler & 0.69 & 1386 & 426 & 0 & 0 \\
\hline Condensing gas boiler & 0 & 0 & 0 & 0 & 0 \\
\hline Air-to-water heat pump & 0 & 0 & 0 & 0 & 0 \\
\hline Ground-to-water heat pump & 0 & 0 & 0 & 0.69 & -34051 \\
\hline Water-water heat pump & 0 & 0 & 0 & 0 & 0 \\
\hline Solar collectors & 0.31 & 0 & 0 & 0.31 & -19867 \\
\hline$\Sigma$ & 1 & - & - & 1 & - \\
\hline Photovoltaic system & 0.007 & 106 & 34 & 0.007 & -1584 \\
\hline Electricity grid & 0.993 & 11437 & 2093 & 0.993 & -27611 \\
\hline$\Sigma$ & 1 & - & - & 1 & \\
\hline Total & - & 12929 & 2106 & - & -156873 \\
\hline Total for $1 \mathrm{~m}^{2}$ & - & 84.2 & 13.7 & - & -1022 \\
\hline
\end{tabular}

\section{Results}

Table 3 presents the results, calculated with the minimized values of the objective function. It is seen that basing on objective function, we get the different combinations. So the next step is to calculate the best solution with the help of MCDM and present the final results. But first of all we should calculate the weights, basing on AHP methodology (Table 4).

Table 4. A pair-wise comparison table of criteria weights

\begin{tabular}{llllll}
\hline & $x_{1}$ & $x_{2}$ & $x_{3}$ & $\Sigma$ & $Q$ \\
\hline$x_{1}$ & & 0.73 & 0.87 & 1.60 & 0.25 \\
$x_{2}$ & 1.37 & & 1.50 & 2.87 & 0.46 \\
$x_{3}$ & 1.15 & 0.67 & & 1.82 & 0.29 \\
\hline
\end{tabular}

This initial decision making matrix, we expressed as a final decision making matrix, is prepared for MCMD calculation (Table 5). Weights are expressed as $q$ and are calculated with AHP method, giving the questioner to the respondents.

Table 5. The final matrix of the initial decisions

\begin{tabular}{|c|c|c|c|}
\hline & \multirow{2}{*}{\multicolumn{3}{|c|}{ Criteria }} \\
\hline & & & \\
\hline & $x_{1}$ & $x_{2}$ & $x_{3}$ \\
\hline & \multicolumn{3}{|c|}{ Optimization direction } \\
\hline & $\min$ & $\min$ & Min \\
\hline$q$ & 0.25 & 0.46 & 0.29 \\
\hline $\mathbf{D}_{1}$ & 84.23 & 16.63 & 1037.90 \\
\hline $\mathbf{D}_{2}$ & 140.59 & 28.02 & 1169,80 \\
\hline $\mathbf{D}_{3}$ & 121.91 & 22.40 & 1045.10 \\
\hline $\mathbf{D}_{4}$ & 107.75 & 19.81 & 1021.80 \\
\hline $\mathbf{D}_{5}$ & 108.77 & 20.00 & 1023.40 \\
\hline$\Sigma$ & 563.25 & 106.86 & 5298.00 \\
\hline Optimal values & 84.23 & 16.63 & 1021.80 \\
\hline
\end{tabular}


The normalized decision making matrix is presented in Table 6 and expresses the normalized values for the decision making method WASPAS.

Table 6. A normalized matrix of the initial decisions

\begin{tabular}{llll}
\hline \multirow{2}{*}{ Alternatives } & \multicolumn{2}{l}{ Criteria } & $\boldsymbol{x}_{\mathbf{2}}$ \\
\cline { 2 - 4 } & $\boldsymbol{x}_{\mathbf{1}}$ & 1.0000 & 0.9845 \\
\hline $\mathbf{D}_{1}$ & 1.0000 & 0.5935 & 0.8735 \\
$\mathbf{D}_{2}$ & 0.5991 & 0.7424 & 0.9777 \\
$\mathbf{D}_{3}$ & 0.6909 & 0.8395 & 1.0000 \\
$\mathbf{D}_{4}$ & 0.7817 & 0.8315 & 0.9984 \\
$\mathbf{D}_{5}$ & 0.7744 & & \\
\hline
\end{tabular}

Weighted and normalized decision making matrix for the summarized and multiplication part of WASPAS method is presented in Table 7.

Table 7. A weighted-normalized decision making matrix for WASPAS method with final results

\begin{tabular}{|c|c|c|c|c|c|c|c|}
\hline \multirow{2}{*}{ Alternatives } & \multicolumn{3}{|c|}{ Values for summarizing part } & \multicolumn{3}{|c|}{ Values for multiplication part } & \multirow[t]{2}{*}{ Final results } \\
\hline & $x_{1}$ & $x_{2}$ & $x_{3}$ & $x_{1}$ & $x_{2}$ & $x_{3}$ & \\
\hline $\mathbf{D}_{1}$ & 0.2545 & 0.4566 & 0.2844 & 1.0000 & 1.0000 & 0.9955 & 0.9955 \\
\hline $\mathbf{D}_{2}$ & 0.1525 & 0.2710 & 0.2524 & 0.8777 & 0.7881 & 0.9617 & 0.6705 \\
\hline $\mathbf{D}_{3}$ & 0.1759 & 0.3389 & 0.2825 & 0.9102 & 0.8729 & 0.9935 & 0.7933 \\
\hline $\mathbf{D}_{4}$ & 0.1990 & 0.3833 & 0.2889 & 0.9392 & 0.9232 & 1.0000 & 0.8691 \\
\hline $\mathbf{D}_{5}$ & 0.1971 & 0.3796 & 0.2885 & 0.9370 & 0.9192 & 0.9995 & 0.8630 \\
\hline
\end{tabular}

Weighted and normalized decision making matrix for TOPSIS method is presented in Table 8 .

Table 8. A weighted-normalized decision making matrix for TOPSIS

\begin{tabular}{llll}
\hline Alternatives & $x_{1}$ & $x_{2}$ & $x_{3}$ \\
\hline $\mathbf{D}_{1}$ & 0.0840 & 0.1564 & 0.1264 \\
$\mathbf{D}_{2}$ & 0.1402 & 0.2636 & 0.1424 \\
$\mathbf{D}_{3}$ & 0.1216 & 0.2107 & 0.1273 \\
$\mathbf{D}_{4}$ & 0.1074 & 0.1863 & 0.1244 \\
$\mathbf{D}_{5}$ & 0.1085 & 0.1881 & 0.1246 \\
$\mathbf{D}+$ & 0.0840 & 0.1564 & 0.1244 \\
$\mathbf{D}-$ & 0.1402 & 0.2636 & 0.1424 \\
\hline
\end{tabular}

Final results of TOPSIS method are presented in Table 9.

Table 9. Decision making matrix for TOPSIS (final results)

\begin{tabular}{|c|c|c|c|c|c|c|c|c|}
\hline $\mathbf{D}_{1}$ & 0 & 0 & $3.84351 \mathrm{E}-06$ & $3.84351 \mathrm{E}-06$ & $\mathrm{LI+}$ & 0.00196 & & \\
\hline $\mathbf{D}_{2}$ & 0.003158178 & 0.01147824 & 0.000324788 & 0.014961206 & $L 2+$ & 0.122316 & & \\
\hline $\mathbf{D}_{3}$ & 0.001411615 & 0.00294564 & 8.04987E-06 & 0.004365304 & L3+ & 0.06607 & $\boldsymbol{K}_{1}$ & 0.98419 \\
\hline $\mathbf{D}_{4}$ & 0.000550008 & 0.00089471 & 0 & 0.001444718 & L4+ & 0.038009 & $\boldsymbol{K}_{2}$ & 0 \\
\hline $\mathbf{D}_{5}$ & 0.000598748 & 0.00100482 & 3.79592E-08 & 0.001603604 & L5+ & 0.040045 & $\boldsymbol{K}_{3}$ & 0.467771 \\
\hline $\mathbf{D}_{1}$ & 0.003158178 & 0.01147824 & 0.000257968 & 0.014894386 & L1- & 0.122043 & $K_{4}$ & 0.692987 \\
\hline $\mathbf{D}_{2}$ & 0 & 0 & 0 & 0 & $L 2-$ & 0 & $K_{5}$ & 0.676541 \\
\hline $\mathbf{D}_{3}$ & 0.000346935 & 0.00279448 & 0.000230574 & 0.003371986 & L3- & 0.058069 & & \\
\hline $\mathbf{D}_{4}$ & 0.001072262 & 0.00596368 & 0.000324788 & 0.007360728 & L4- & 0.085795 & & \\
\hline $\mathbf{D}_{5}$ & 0.001006688 & 0.00569084 & 0.000317804 & 0.007015335 & $L 5$ & 0.083758 & & \\
\hline
\end{tabular}


Both methods showed the same results: the firs alternative $\boldsymbol{D}_{1}$ is the best solution to this case study, which means that the house, heated with the wood boiler with the integrated solar collector and photovoltaic systems is the best solution. Worse results showed the alternative number $\boldsymbol{D}_{2}$, the gas boiler with the integrated solar collector. The next researches could be based on the possibility to combine the referred technologies, in order to get the best solution.

\section{Conclusions}

1. The presented combinations of the technologies of the building energy system were simulated with Polysun software. Using evolutionary solving method it was tried to evaluate the best solution. However, considering that the general criteria of presented alternatives have different dimensions, the comparison of alternatives and the making of the decision become a complex task.

2. Decision making methods are useful in making the decision in civil engineering tasks, especially if the case study is multidimensional.

3. TOPSIS and WASPAS methods were presented as a methodology for decision making between presented alternatives; and seems to be useful, as their results were similar.

4. The results generated by WASPAS and TOPSIS methods showed that the best solution for the presented building is the wood boiler with the integrated solar collector and photovoltaic systems.

\section{References}

[1] Kibert, C. J.; Fard, M.M. 2012. Differentiating among low-energy, low-carbon and net-zero-energy building strategies for policy formulation, Building Research \& Information 40(5): 625-637. http://dx.doi.org/10.1080/09613218.2012.703489

[2] Hernandez, P.; Kennyc, P. 2011. Development of a methodology for life cycle building energy ratings, Energy Policy 39: $3779-3788$. http://dx.doi.org/10.1016/j.enpol.2011.04.006

[3] Džiugaitè-Tumėnienè, R.; Medineckienè, M. 2013. Daugiakriterių metodų taikymas racionaliam pastato energetinès sistemos technologijų deriniui nustatyti, Mokslas - Lietuvos ateitis 5(4): 410-422. http://dx.doi.org/10.3846/mla.2013.65

[4] Zavadskas, E. K.; Turskis, Z.; Antucheviciene, J.; Zakarevicius, A. Optimization of weighted aggregated sum product assessment, Electronics and Electrical Engineering 6(122): 3-6.

[5] Hwang, C.L.; Yoon, K. S. 1981. Multiple Attribute Decision Making: Methods and Applications. Springer-Verlag. Berlin, Heidelberg, New York. http://dx.doi.org/10.1007/978-3-642-48318-9

[6] Staniunas, M.; Medineckiene, M.; Zavadskas, E. K.; Kalibatas, D. 2013. To modernize or not: Ecological-economical assessment of multi-dwelling houses modernization, Archives of civil and mechanical engineering 13: 88-98.

[7] Saaty, T. L.; Erdener, E. 1979. A new approach to performance measurement the analytic hierarchy process, Design Methods and Theories 13(2): 6268.

[8] Podvezko, V. 2009. Application of AHP technique, Journal of Business Economics and Management 10(2): 181-189. http://dx.doi.org/10.3846/16111699.2009.10.181-189 